\title{
Oxidative Stress as a Possible Mechanism of Toxicity of the Herbicide 2,4- Dichlorophenoxyacetic Acid (2,4-D)
}

\author{
Bettina Bongiovanni ${ }^{1}$, Cintia Konjuh ${ }^{1}$, \\ Arístides Pochettino ${ }^{1}$ and Alejandro Ferri ${ }^{2}$ \\ ${ }^{1}$ Laboratorio de Toxicología Experimental, Departamento de \\ Ciencias de los Alimentos y Medio Ambiente; \\ ${ }^{2}$ Departamento de Química Analítica, Facultad de Ciencias Bioquímicas y Farmacéuticas, \\ Universidad Nacional de Rosario, Rosario, \\ Argentina
}

\section{Introduction}

Chlorophenoxy herbicides are widely used in agriculture and forestry, for the control of broad-leaved weeds in pastures, cereal crops, as well as along public rights of way. Structurally, these herbicides consist of a simple aliphatic carboxylic acid moiety attached to a chlorine-substituted aromatic ring via an ether linkage. One of the most commonly used herbicides of this type is 2,4-dichlorophenoxyacetic acid (2,4-D) (Fig. 1). In congruence with the similitude between its molecular structure and that of the plant hormone indole-acetic acid, 2,4-D acts as a plant growth regulator that can interfere with normal hormonal action and plant growth (Munro et al., 1992).<smiles>O=C(O)COc1ccc(Cl)cc1Cl</smiles>

Fig. 1. Structure of the 2,4-Dichlorophenoxyacetic Acid.

2.4-D was synthesized for the first time in 1941 and commercially marketed in the United States (U.S.) in 1944 (IARC, 1986) and worldwide since 1950 (Munro et al. 1992). The widespread use of 2,4-D as a domestic herbicide and as a component of Orange Agent encouraged the study of its toxicity.

Human exposure to chlorophenoxy herbicides may occur through inhalation, skin contact or ingestion. The predominant route for occupational exposure to 2,4-D has been the absorption of spills or aerosol droplets through the skin.

Several studies have shown that doses of 50,70 or $100 \mathrm{mg} / \mathrm{kg}$ body weight (bw)/day of 2,4D produce a wide range of toxic effects on the embryo and on the reproductive and neural 
systems in animal (mostly rat) and human models (Rosso et al., 2000; Barnekow et al., 2001; Charles et al., 2001). Doses of $50 \mathrm{mg} / \mathrm{kg}$ bw/day of 2,4-D have been reported to increase ventral prostate weight in rats. Treatment of human prostate cancer cell cultures with $10 \mathrm{nM}$ 2,4-D enhanced the androgenic activity of dihydroxytestosterone (DHT) on cell proliferation and transactivation (Kim et al., 2005). In cultured chinese-hamster ovary cells, 2.0 to 10.0 $\mu \mathrm{g} / \mathrm{ml} 2,4-\mathrm{D}$ were reported to produce DNA damage and sister chromatid exchange (Gonzalez et al., 2005). Importantly, although the 2,4-D toxicity in low doses is controversial, the U.S. Environmental Protection Agency (U.S. EPA, 2006) established a LD50 of 639 $\mathrm{mg} / \mathrm{kg}$ based on rat studies.

There could be particular situations in which the susceptibility of a population exposed to environmental pollutants can be dangerously enhanced. This may be the case for many rural populations subjected to some specific nutritional deficiencies, as often observed in developing countries. Such situation may be worthy of attention during the development stage, especially concerning the endocrine and nervous systems.

It has been recently found that 2,4-D administered to lactating rats can pass to suckling pups, an can also inhibit the suckling-induced hormone release in the mother. Thus, gestational and lactational periods -including the neonatal and prepubertal stages- seem to be particularly favorable for the induction of 2,4-D effects in rodents (Stürtz et al., 2000; 2006).

\section{Adverse effects on developing nervous system}

In human studies, prenatal exposure to 2,4-D was associated with mental retardation of the children (Casey, 1984). Comparable animal experiments in chicken and rats showed that prenatal exposure altered some behavioral patterns of the offspring (Sanders \& Rogers, 1981; Sjoden \& Soderberg, 1972).

In the rat, one critical period for normal maturation during growth seems to be that corresponding to the perinatal development of the brain - "the brain growth spurt" spanning the first 3 or 4 weeks of life (Diaz \& Samson, 1980). Therefore, exposure of rats to pesticides during the first weeks of life would have adverse effects on growth and behavior, as well as on the locomotor activity, as affected by anatomical changes. Noteworthy, the age at exposure is an important factor (Kolb \& Wishaw, 1989).

This selective susceptibility of the developing nervous system may be due to several toxicokinetic factors and a partial lack of a blood-brain barrier (BBB) in the fetus. In humans, the BBB is not fully developed until the middle of the first year of life (Rodier, 1995).

Gupta et al. (1999) have shown that different classes of pesticides are able to change the permeability characteristics of the BBB in rats when administered during some susceptible periods of the BBB development, and that this effect may persist after exposure for variable periods. An altered BBB may render the nervous system more vulnerable to other toxics that would not be able to pass the BBB otherwise.

Therefore, although the developing nervous system has some capacity to adapt to or compensate for early perturbations, many chemical agents have been shown more toxic on the developing than on the adult nervous system (Tilson, 1998). 
In the last two decades many different alterations have been reported in neonatal rats exposed to 2,4-D through breast milk, at a dose producing no overt signs of toxicity in dams. Alterations in astroglial cytoarchitecture and neuronal function (Brusco et al., 1997) as well as neuro-behavioral changes were observed in pups and adult rats after an early exposition to the herbicide (Bortolozzi et al., 1999, 2001). Other reported effects in neonate rats were a deficit in myelin lipid deposition (Konjuh et al., 2008) and changes in the ganglioside pattern in some brain regions (Rosso et al., 2000).

\subsection{Metals and monoamines levels}

Studies in well-fed or undernourished rat offsprings showed that the mechanisms for the induction of the above effects would include some changes in brain monoaminergic system (Ferri et al., 2000) and in iron (Fe), copper ( $\mathrm{Cu})$ and zinc (Zn) brain levels (Ferri et al., 2003).

Importantly, the combination of neonatal undernourishment plus mothers' exposure at 2,4$\mathrm{D}$ low dose $(70 \mathrm{mg} / \mathrm{kg} \mathrm{bw})$ induced a higher modification of the measured parameters than those induced by undernourishment or 2,4-D exposure alone. The data showed a different pup's brain areas susceptibility to the 2,4-D effects and an increased vulnerability to the herbicide, including an increased mortality at a higher dose $(100 \mathrm{mg} / \mathrm{kg} \mathrm{bw})$, a feature which was not observed in well-nourished animals.

In addition, the results suggest that malnutrition or exposure to 2,4-D exert their effects independently (Tables 1 \& 2) (Ferri et al., 2003) and the fact that the alterations observed are very different according to the area involved, reinforces the idea of a selective susceptibility for each brain region.

\subsection{Oxidative stress}

Different studies suggest some functional relationships between the oxidative status of the Central Nervous System (CNS) and the protecting level of catecholamines (Kumiko et al., 2001) and metals, like $\mathrm{Fe}$ and $\mathrm{Cu}$, the major generators of reactive oxygen species -ROS- in Alzheimer's disease (Huang et al., 1999), related with a decreased glutathione (GSH) content (Dringer, 2000) and also involved in Fenton's and Haber Weiss' redox reactions . (Halliwell \& Gutteridge, 1998; Milton, 2004). Other data have shown that 2,4-D affects the redox chain, thus altering cell energetic metabolism and redox balance (Palmeira et al., 1994; Sulik et al., 1998; Bukowska et al., 2003; Duchnowicz et al., 2002).

In rat pups, exposure to 2,4-D through breast milk induced a number of changes in different brain areas, such as disparate changes in the activity of some protective enzymes, an increase in reactive oxygen species (ROS) levels, and a depletion of reduced glutathione (GSH) content (Tables 3, 4 \& 5, respectively) (Ferri et al., 2007).

Therefore, as long as a high oxygen consumption by the CNS increases its sensitivity to oxidative stress (Emerit et al., 2004), the observed changes in the levels of metal ions and neurotransmitters, particularly catecholamines, as well as the oxidative status imbalance, would point out oxidative stress as one possible mechanism of adverse 2,4-D effects on the CNS. 


\begin{tabular}{lcccccccc}
\hline AREA & Treatment & NE & DA & DOPAC & HVA & TRP & 5-HT & 5-HIAA \\
\hline PFc & DMSO & $0.93 \pm 0.04$ & $3.20 \pm 0.44$ & $0.97 \pm 0.09$ & $0.28 \pm 0.03$ & $20.71 \pm 0.61$ & $1.07 \pm 0.13$ & $1.08 \pm 0.07$ \\
& 2,4-D & $1.10 \pm 0.06^{*}$ & $2.01 \pm 0.30^{*}$ & $0.90 \pm 0.17$ & $0.25 \pm 0.03$ & $11.26 \pm 0.51^{* *}$ & $1.48 \pm 0.09^{*}$ & $1.03 \pm 0.05$ \\
& & $(\uparrow 20 \%)$ & $(\downarrow 37 \%)$ & & & $(\downarrow 46 \%)$ & $(\uparrow 38 \%)$ & \\
Str & DMSO & $4.24 \pm 0.42$ & $20.79 \pm 1.61$ & $9.37 \pm 0.48$ & $3.19 \pm 0.12$ & $27.46 \pm 1.61$ & $2.98 \pm 0.31$ & $2.84 \pm 0.29$ \\
& 2,4-D & $2.36 \pm 0.44^{*}$ & $17.03 \pm 3.31$ & $6.96 \pm 0.69^{* *}$ & $2.05 \pm 0.32^{* *}$ & $28.06 \pm 1.76$ & $1.85 \pm 0.25^{*}$ & $2.81 \pm 0.42$ \\
& & $(\downarrow 44 \%)$ & & $(\downarrow 26 \%)$ & $(\downarrow 36 \%)$ & & $(\downarrow 38 \%)$ & \\
Hipp & DMSO & $0.91 \pm 0.12$ & $0.70 \pm 0.09$ & $0.44 \pm 0.07$ & $0.30 \pm 0.04$ & $5.55 \pm 0.35$ & $0.74 \pm 0.09$ & $1.63 \pm 0.11$ \\
& 2,4-D & $1.67 \pm 0.24^{*}$ & $0.92 \pm 0.09^{*}$ & $0.58 \pm 0.06^{*}$ & $0.50 \pm 0.05^{*}$ & $3.68 \pm 0.20^{* *}$ & $1.10 \pm 0.13^{*}$ & $1.75 \pm 0.10$ \\
& & $(\uparrow 83 \%)$ & $(\uparrow 31 \% \%)$ & $(\uparrow 31 \%)$ & $(\uparrow 66 \%)$ & $(\downarrow 34 \%)$ & $(\uparrow 49 \%)$ & \\
Hyp & DMSO & $9.05 \pm 1.19$ & $1.58 \pm 0.35$ & $1.46 \pm 0.21$ & $1.08 \pm 0.20$ & $3.81 \pm 0.26$ & $1.52 \pm 0.13$ & $3.09 \pm 0.59$ \\
& 2,4-D & $13.57 \pm 1.44^{*}$ & $1.80 \pm 0.33$ & $1.03 \pm 0.17$ & $1.14 \pm 0.18$ & $2.96 \pm 0.35$ & $2.08 \pm 0.31$ & $2.68 \pm 0.26$ \\
MB & & $(\uparrow 50 \%)$ & & & & & & \\
& DMSO & $3.16 \pm 0.57$ & $1.54 \pm 0.31$ & $0.65 \pm 0.14$ & $0.36 \pm 0.06$ & $31.88 \pm 1.21$ & $2.79 \pm 0.21$ & $3.54 \pm 0.40$ \\
& 2,4-D & $3.96 \pm 0.17$ & $1.96 \pm 0.17$ & $0.78 \pm 0.12$ & $0.24 \pm 0.02$ & $23.34 \pm 0.97^{* *}$ & $4.14 \pm 0.19^{* *}$ & $4.78 \pm 0.37^{*}$ \\
Cereb & DMSO & $1.58 \pm 0.12$ & $0.17 \pm 0.06$ & $0.31 \pm 0.01$ & $0.09 \pm 0.01$ & $7.39 \pm 0.55$ & $0.46 \pm 0.03$ & $0.48 \pm 0.03$ \\
& 2,4-D & $2.44 \pm 0.08^{* *}$ & $0.21 \pm 0.04$ & $0.29 \pm 0.01$ & $0.13 \pm 0.01$ & $4.86 \pm 0.21^{* *}$ & $0.43 \pm 0.04$ & $0.43 \pm 0.02$ \\
& & $(\uparrow 54 \%)$ & & & & $(\downarrow 34 \%)$ & \\
\hline
\end{tabular}

Monoamine content is expressed as $\mathrm{pMol} / \mathrm{mg}$ of tissue. Values indicate means $\pm \mathrm{SEM}$. Values between brackets are \% of increase $(\uparrow)$ or decrease $(\downarrow)$, respectively, with respect to each DMSO control value.* ${ }^{*}$ $<0.05 ;{ }^{* *} \mathrm{p}<0.01 ; \mathrm{n}=6$ / group; $100 \mathrm{mg}$ 2,4-D/kg cw of mother. PFc (Pre frontal cortex), Str (Striatum), Hipp (Hippocampus), Hyp (Hypothalamus), MB (Midbarin), Cereb (Cerebellum), NE

(Norepinephrine), DA (Dopamine), DOPAC (3,4-Dihydroxyphenylacetic acid), HVA (Homovanillic Acid), TRP (Tryptophan), 5-HT (Serotonin) and 5-5-HIAA (Hydroxyindoleacetic acid); other abbreviations as indicated in the text.

Table 1. Monoamine levels in different brain areas of 25-day-old, 2,4-D-expossed pups.

\begin{tabular}{|c|c|c|c|c|c|c|c|}
\hline Metal & Treatment & PFc & Str & Cereb & Hipp & MB & Hyp \\
\hline \multirow[t]{3}{*}{$\mathbf{F e}$} & DMSO & $19.58 \pm 2.36$ & $17.07 \pm 0.90$ & $16.43 \pm 1.27$ & $14.23 \pm 0.73$ & $18.79 \pm 2.03$ & $19.48 \pm 2.25$ \\
\hline & 2,4-D 70 mg/kg & $\begin{array}{l}24.48 \pm 1.83^{*} \\
(\uparrow 25.05 \%)\end{array}$ & $16.65 \pm 2.65$ & $17.53 \pm 0.86$ & $12.86 \pm 1.20$ & $15.54 \pm 0.55$ & $20.95 \pm 1.76$ \\
\hline & 2,4-D $100 \mathrm{mg} / \mathrm{kg}$ & $\begin{array}{l}29.48 \pm 2.19^{*} \\
(\uparrow 50.56 \%)\end{array}$ & $15.75 \pm 2.65$ & $\begin{array}{l}20.26 \pm 0.68^{*} \\
(\uparrow 23.31 \%)\end{array}$ & $13.98 \pm 1.80$ & $14.95 \pm 0.35$ & $21.31 \pm 2.68$ \\
\hline \multirow[t]{3}{*}{ Zn } & DMSO & $12.51 \pm 1.20$ & $34.10 \pm 2.40$ & $24.40 \pm 1.90$ & $25.40 \pm 2.10$ & $32.65 \pm 1.10$ & $29.80 \pm 3.40$ \\
\hline & 2,4-D $70 \mathrm{mg} / \mathrm{kg}$ & $14.64 \pm 2.20$ & $\begin{array}{l}28.63 \pm 2.40^{*} \\
(\downarrow 16.04 \%)\end{array}$ & $21.50 \pm 0.85$ & $\begin{array}{l}27.89 \pm 1.60^{*} \\
(\uparrow 9.80 \%)\end{array}$ & $29.55 \pm 1.74$ & $27.11 \pm 2.56$ \\
\hline & 2,4-D $100 \mathrm{mg} / \mathrm{kg}$ & $\begin{array}{l}17.93 \pm 2.00^{*} \\
(\uparrow 43.32 \%)\end{array}$ & $\begin{array}{l}13.10 \pm 2.00^{* *} \\
(\downarrow 61.58 \%)\end{array}$ & $24.40 \pm 0.70$ & $\begin{array}{l}34.30 \pm 3.50^{*} \\
(\uparrow 35.04 \%)\end{array}$ & $\begin{array}{l}24.35 \pm 1.54^{* *} \\
(\downarrow 25.42 \%)\end{array}$ & $26.37 \pm 3.20$ \\
\hline \multirow[t]{3}{*}{$\mathrm{Cu}$} & DMSO & $1.85 \pm 0.08$ & $2.25 \pm 0.11$ & $1.88 \pm 0.07$ & $1.84 \pm 0.02$ & $2.21 \pm 0.19$ & $1.95 \pm 0.08$ \\
\hline & 2,4-D 70 mg/kg & $1.97 \pm 0.18$ & $2.17 \pm 0.13$ & $2.00 \pm 0.10$ & $2.01 \pm 0.20$ & $2.16 \pm 0.21$ & $1.91 \pm 0.16$ \\
\hline & 2,4-D $100 \mathrm{mg} / \mathrm{kg}$ & $\begin{array}{l}2.31 \pm 0.21^{*} \\
(\uparrow 24.86 \%)\end{array}$ & $2.38 \pm 0.21$ & $\begin{array}{l}2.20 \pm 0.08^{* *} \\
(\uparrow 17.02 \%)\end{array}$ & $\begin{array}{l}2.23 \pm 0.17^{*} \\
(\uparrow 21.19 \%)\end{array}$ & $2.14 \pm 0.20$ & $1.91 \pm 0.15$ \\
\hline
\end{tabular}

Metal contents are expressed as micrograms per gram of wet tissue. Values indicate means \pm SEM. Values between brackets are \% of increase $(\uparrow)$ or decrease $(\downarrow)$, respectively, with respect to each DMSO control value. ${ }^{*} \mathrm{p}<0.05$ with reference to DMSO control values. ${ }^{* *} \mathrm{p}<0.01$ with reference to DMSO control values; $\mathrm{n}=6$ / group. $100 \mathrm{mg}$ 2,4-D/kg cw of mother. PFc (Pre frontal cortex, Str (Striatum), Cereb (Cerebellum), Hipp (Hippocampus), MB (Midbarin), Hyp (Hypothalamus), and other abbreviations as in the text.

Table 2. Effects of 2,4-D on iron, zinc and copper levels in different brain areas of wellnourished pups. 
Oxidative Stress as a Possible Mechanism

\begin{tabular}{lcccccccc}
\hline Enzime & Treatment & Brain & PFc & Str & Cereb & Hipp & MB & Hyp \\
\hline Cu,Zn- & DMSO & $2330 \pm 119$ & $1950 \pm 200$ & $2460 \pm 150$ & $2730 \pm 330$ & $2330 \pm 200$ & $1950 \pm 120$ & $2320 \pm 160$ \\
SOD & 2,4-D & $2400 \pm 93$ & $2450 \pm 310^{*}$ & $2540 \pm 220$ & $2610 \pm 240$ & $2980 \pm 320^{*}$ & $2140 \pm 90$ & $2400 \pm 120$ \\
& & & $(\uparrow 25.6 \%)$ & & & $(\uparrow 27.9 \%)$ & & \\
Mn- & DMSO & $250 \pm 110$ & $250 \pm 80$ & $310 \pm 120$ & $320 \pm 130$ & $270 \pm 90$ & $240 \pm 120$ & $370 \pm 140$ \\
SOD & 2,4-D & $284 \pm 135$ & $150 \pm 70$ & $280 \pm 100$ & $280 \pm 90$ & $390 \pm 60$ & $290 \pm 110$ & $350 \pm 110$ \\
& & & & & & & \\
CAT & DMSO & $2556 \pm 150$ & $2950 \pm 250$ & $2740 \pm 200$ & $2300 \pm 130$ & $2580 \pm 160$ & $2360 \pm 200$ & $2740 \pm 150$ \\
& 2,4-D & $1978 \pm 133^{*}$ & $2200 \pm 200^{*}$ & $2250 \pm 150^{*}$ & $2530 \pm 170$ & $2690 \pm 210$ & $1850 \pm 120^{*}$ & $2810 \pm 210$ \\
Se- & DMSO & $(\downarrow 22.5 \%)$ & $(\downarrow 25.4 \%)$ & $(\downarrow 17.9 \%)$ & & & $(\downarrow 21.6 \%)$ & \\
GPx & 2,4-D & $26.76 \pm 1.24$ & $30.00 \pm 1.43$ & $28.19 \pm 2.10$ & $25.62 \pm 9.10$ & $29.05 \pm 1.14$ & $31.93 \pm 1.06$ & $28.89 \pm 1.85$ \\
& & $(\downarrow 15.10 \%)$ & $(\downarrow 19.4 \%)$ & $(\downarrow 20.9 \%)$ & $(\uparrow 15.2 \%)$ & $(\uparrow 11.1 \%)$ & $(\downarrow 13.6 \%)$ & \\
noSe- & DMSO & $17.71 \pm 0.69$ & $20.80 \pm 1.08$ & $18.55 \pm 0.62$ & $18.18 \pm 0.98$ & $20.94 \pm 0.69$ & $22.65 \pm 0.77$ & $15.81 \pm 0.69$ \\
GPx & 2,4-D & $20.32 \pm 0.94^{*}$ & $18.99 \pm 0.99$ & $15.65 \pm 0.46^{*}$ & $17.95 \pm 1.05$ & $19.90 \pm 0.87$ & $19.35 \pm 0.82^{*}$ & $17.01 \pm 0.71$ \\
& & $(\uparrow 14.7 \%)$ & & $(\downarrow 15.6 \%)$ & & & $(\downarrow 14.6 \%)$ & \\
\hline
\end{tabular}

Enzyme activities are expresed as miliUnits per miligram of protein. Values indicate means \pm SEM. Values between brackets are \% of increase $(\uparrow)$ or decrease $(\downarrow)$, respectively, with respect to each DMSO control value. * $\mathrm{p}<0.05, \mathrm{n}=6$ /group. $100 \mathrm{mg}$ 2,4-D/kg cw of mother. PFc (Pre frontal cortex, Str (Striatum), Hipp (Hippocampus), Hyp (Hypothalamus), MB (Midbarin), Cereb (Cerebellum), Cu,ZnSOD (Copper,Zinc superoxide dismutase), Mn-SOS (Manganese superoxide dismutase), CAT (catalase), Se-GPx (selenium-glutathione peroxidase), noSe-GPx (non selenium-glutathione peroxidase), and other abbreviations as in the text

Table 3. Protective Enzymes Activities in brain areas of 25-old-day pups lactationally exposed to 2,4-D.

\begin{tabular}{|c|c|c|c|c|c|c|c|}
\hline & Brain & PFc & Str & Cereb & Hipp & MB & Hyp \\
\hline DMSO & $45.1 \pm 2.5$ & $17.8 \pm 0.7$ & $22.6 \pm 0.8$ & $24.0 \pm 0.9$ & $18.0 \pm 1.0$ & $20.3 \pm 1.0$ & $22.6 \pm 1.2$ \\
\hline 2,4-D & $\begin{array}{l}38.0 \pm 1.4^{*} \\
(\downarrow 15.7 \%)\end{array}$ & $\begin{array}{l}20.6 \pm 0.5^{*} \\
(\uparrow 15.7 \%)\end{array}$ & $\begin{array}{l}25.1 \pm 0.7^{*} \\
(\uparrow 11.1 \%)\end{array}$ & $23.7 \pm 1.1$ & $18.1 \pm 1.1$ & $\begin{array}{l}23.8 \pm 0.7^{*} \\
(\uparrow 17.2 \%)\end{array}$ & $21.1 \pm 1.3$ \\
\hline
\end{tabular}

ROS levels are expresed as IF per mg of protein. Values indicate means \pm SEM. Values between brackets are $\%$ of increase $(\uparrow)$ or decrease $(\downarrow)$, respectively, with respect to each DMSO control value.; ${ }^{*} p<0.05$, n=6/group. $100 \mathrm{mg}$ 2,4-D/kg cw of mother. PFc (Pre frontal cortex, Str (Striatum), Hipp (Hippocampus), Hyp (Hypothalamus), MB (Midbarin), Cereb (Cerebellum), other abbreviations as in the text.

Table 4. ROS levels in brain areas of 25-old-day pups lactationally exposed to 2,4-D.

\begin{tabular}{cccccccc}
\hline & Brain & PFc & Str & Cereb & Hipp & MB & Hyp \\
\hline DMSO & $1.22 \pm 0.40$ & $1.23 \pm 0.29$ & $1.31 \pm 0.24$ & $0.79 \pm 0,19$ & $0.88 \pm 0.19$ & $1.06 \pm 0.12$ & $1.07 \pm 0.41$ \\
& & & $0.82 \pm 0.18^{*}$ & $0.80 \pm 0.22$ & $0.94 \pm 0.24$ & $\begin{array}{r}0.70 \pm 0.15^{*} \\
(\downarrow 34.0 \%)\end{array}$ & $1.08 \pm 0.30$ \\
\hline
\end{tabular}

GSH levels are expresed as microgram per miligram of protein. Values indicate means \pm SEM. Values between brackets are \% of increase $(\uparrow)$ or decrease $(\downarrow)$, respectively, with respect to each DMSO control value. * $\mathrm{p}<0.05, \mathrm{n}=6$ / group. $100 \mathrm{mg}$ 2,4-D/kg bw of mother. PFc (Pre frontal cortex, Str (Striatum), Hipp (Hippocampus), Hyp (Hypothalamus), MB (Midbarin), Cereb (Cerebellum), other abbreviations as in the text.

Table 5. GSH levels in brain areas of 25-old-day pups lactationally exposed to 2,4-D. 


\section{Prostate, ovary and breast}

The endocrine system of many vertebrate embryos seems to be particularly susceptible to a variety of substances or either natural or anthropogenic origin, including pesticides (Crews et al., 2000). However, there are few studies on developmental toxicology that focus on the 2,4-D's effects on hormone-sensitive organs such as the prostate, ovary and breast.

Free radicals are associated with oxidative stress and are also thought to play some significant roles in reproduction. Induction of oxidative stress by many environmental contaminants - such as pesticides - has also been pointed out during the last decade as a possible mechanism of some toxic effects on the reproductive system (Bagchi et al., 1992; Abdollahi et al., 2004). It is already known that reproductive cells and tissues will remain stable only when antioxidant and oxidant status are in balance (Lee et al., 2010). ROS levels are a double-edged sword, as long as they not only serve as key signal molecules in physiological processes, but also have a role in pathological processes involving the female reproductive tract (Agarwal et al., 2005).

On the other hand, there are diverse environmental chemical contaminants which can be potentially harmful to the mammary gland in association with estrogens. Oxidative catabolism of both estrogen and those compounds, a mechanism mediated by the same enzymes, generates reactive free radicals that can cause oxidative damage. Xenobiotic chemicals may exert their pathological effects through generation of reactive free radicals (Mukherjee et al., 2006).

There is growing evidence that free radicals can exert a wide spectrum of deleterious effects on the reproductive system and asocciated glands (Saradha et al., 2008). Thus, Pochettino et al. (2010) investigated the effect of 2,4-D on oxidative stress and antioxidative system and on some hormone-sensitive organs such as ventral prostate, ovaries and breasts, exposed to the herbicide during the pre- and the postnatal period, as described next (Pochettino et al., 2010).

\subsection{Prostate}

In rat ventral prostate, 2,4-D caused oxidative stress during the whole development, through a significant increase in lipid peroxides, hydroxyl radical levels and protein oxidation. Morevover, the antioxidant enzyme activity was increased at any age, as shown for Glutathione S-transferase (GST), catalase (CAT) and selenium-glutathione peroxidase (Se-GPx), with the exception of Se-GPx administered at the 90 $0^{\text {th }}$ postnatal day (PND 90). Nevertheless, at PND 90 a reduced activity of Glutathione Reductase (GR) was detected (Table 6).

GST is relevant to detoxification of endogenous compounds and xenobiotic substances such as environmental pollutants, drugs, and natural toxins (Pietsch et al., 2001; Padros et al., 2003; Cazenave et al., 2006). Several studies have demonstrated that enhanced GST activity by ROS in the testis could represent an adaptative response to oxidative stress, probably targeted to achieve a detoxification of peroxide-containing metabolites (Kaur et al., 2006).

As far as the testis is intimately related to the prostate, this interpretation looks coherent with the observed ROS-induced increase in GST activity in the prostate. 


\begin{tabular}{lcccc}
\hline & & PND 45 & PND 60 & PND 90 \\
\hline Hydroxyl & Control & $3.25 \pm 0.34$ & $2.97 \pm 0.39$ & $1.09 \pm 0.13$ \\
radical & 2,4-D & $8.75 \pm 0.61^{*}(\uparrow 169 \%)$ & $6.53 \pm 0.09^{*}(\uparrow 119 \%)$ & $2.03 \pm 0.18^{*}(\uparrow 85 \%)$ \\
Carbonyl & Control & $3.54 \pm 0.12$ & $10.66 \pm 1.07$ & $7.02 \pm 0.88$ \\
groups & 2,4-D & $4.84 \pm 0.11^{*}(\uparrow 37 \%)$ & $15.01 \pm 1.32^{*}(\uparrow 47 \%)$ & $12.42 \pm 1.11^{*}(\uparrow 77 \%)$ \\
Total & Control & $491 \pm 12$ & $642 \pm 86$ & $341 \pm 24$ \\
Thiols & 2,4-D & $520 \pm 14$ & $748 \pm 14$ & $333 \pm 8$ \\
& Control & $29.09 \pm 0.32$ & $27.74 \pm 3.74$ & $38.27 \pm 2.14$ \\
MDA & 2,4-D & $41.91 \pm 3.05^{*}(\uparrow 44 \%)$ & $42.69 \pm 3.13^{*}(\uparrow 54 \%)$ & $47.48 \pm 2.54^{*}(\uparrow 24 \%)$ \\
& Control & $8.93 \pm 0.67$ & $10.53 \pm 2.53$ & $13.37 \pm 2.09$ \\
GST & 2,4-D & $19.07 \pm 2,45^{*}(\uparrow 113 \%)$ & $15.95 \pm 1.04^{*}(\uparrow 45)$ & $18.14 \pm 0.26^{*}(\uparrow 36)$ \\
& Control & $10.93 \pm 1,20$ & $5.44 \pm 0.21$ & $5.99 \pm 0.21$ \\
CAT & 2,4-D & $14.74 \pm 1.26^{*}(\uparrow 35 \%)$ & $11.44 \pm 0.34^{*}(\uparrow 110 \%)$ & $7.77 \pm 0.39^{*}(\uparrow 28 \%)$ \\
& Control & $312 \pm 18$ & $518 \pm 57$ & $562 \pm 32$ \\
Se-GPx & 2,4-D & $436 \pm 33^{*}(\uparrow 36)$ & $880 \pm 41^{*}(\uparrow 70 \%)$ & $530 \pm 13$ \\
& Control & $10.05 \pm 0.86$ & $33.01 \pm 2.52$ & $31.09 \pm 4.36$ \\
GR & 2,4-D & $10.47 \pm 1.78$ & $37.75 \pm 3.48$ & $10.57 \pm 0.05^{*}(\downarrow 72 \%)$ \\
\hline
\end{tabular}

Hydroxy radical are expresed as 2,3 dihydroxybenzoic acid/salicilc acid rario; carbonyl groups and total thiols are expresed as micromol per miligram of protein; MDA is expresed as nanomol per microgram of protein. GST, CAT and GR activities are expresed as Units per miligram of protein; and Se-GPx is expresed as miliUnits per miligram of protein. Each value is the mean \pm SEM. Values between brackets are $\%$ of increase $(\uparrow)$ or decrease $(\downarrow) ;{ }^{*} p<0.05, n=6 /$ group. $70 \mathrm{mg} 2,4$-D/kg cw of mother. Abbreviations as in the text.

Table 6. Oxidative parameters in ventral prostate.

Therefore, the 2,4-D-induced increase in all ROS level, lipid peroxidation and protein oxidation may have caused some critical oxidative stress in ventral prostate. Nevertheless, the increased activity of some antioxidant enzymes in the prostate could have not been strong enough as to counteract the oxidative stress produced by the herbicide at different stages of rat development. Moreover, it is not a general rule that increase in oxidative species stimulates antioxidant activity (Celik \& Tuluce, 2007).

\subsection{Ovary}

The complex ovarian structure varies widely during differentiation. Free radicals play important regulating roles during the ovarian follicular cycle, possibly through inhibition of steroid production (Behrman et al., 2001). There is also a delicate balance between ROS and antioxidant enzymes in the ovarian tissues (Agarwal et al., 2005). Non-physiological effects of free radicals include premature ovarian follicular atresia via cell apoptosis. Many pesticides - e.g. the xenoestrogen pesticide methoxychlor - can induce oxidative stress and apoptosis in the ovary (Gupta et al., 2006). Moreover, clinical studies have reported increased levels of reactive oxygen species associated to a decreased female fertility (Agarwal et al., 2006). 


\begin{tabular}{lcccc}
\hline & & PND 45 & PND 60 & PND 90 \\
\hline Hydroxyl & Control & $3.65 \pm 0.26$ & $1.89 \pm 0.22$ & $1.09 \pm 0.13$ \\
radical & 2,4-D & $8.75 \pm 0.89$ & $1.98 \pm 0.13$ & $4.35 \pm 0.53^{*}(\uparrow 93 \%)$ \\
Carbonyl & Control & $14.77 \pm 2.75$ & $5.74 \pm 0.13$ & $6.22 \pm 0.94$ \\
groups & 2,4-D & $23.71 \pm 0.47^{*}(\uparrow 60 \%)$ & $8.80 \pm 0.72^{*}(\uparrow 55 \%)$ & $5.64 \pm 0.73$ \\
Total & Control & $1462 \pm 162$ & $672 \pm 24$ & $519 \pm 38$ \\
Thiols & 2,4-D & $1360 \pm 176$ & $676 \pm 39$ & $537 \pm 22$ \\
& Control & $87.71 \pm 14.02$ & $34.12 \pm 2.24$ & $34.68 \pm 1.31$ \\
MDA & 2,4-D & $192.5 \pm 17.8^{*}(\uparrow 119 \%)$ & $42.49 \pm 1.35^{*}(\uparrow 24 \%)$ & $39.39 \pm 0.89^{*}(\uparrow 14 \%)$ \\
& Control & $38.51 \pm 0.41$ & $10.59 \pm 0.81$ & $10.99 \pm 0.18$ \\
GST & 2,4-D & $25.15 \pm 1.37(\downarrow 34.6 \%)$ & $7.97 \pm 0.54^{*}(\downarrow 24.7)$ & $9.91 \pm 0.57$ \\
& Control & $42.89 \pm 3.14$ & $27.86 \pm 1.08$ & $16.08 \pm 0.42$ \\
CAT & 2,4-D & $43.41 \pm 0.67$ & $15.34 \pm 0.43^{*}(\downarrow 44.9 \%)$ & $16.38 \pm 0.71$ \\
& Control & $691 \pm 97$ & $411 \pm 48$ & $514 \pm 29$ \\
Se-GPx & 2,4-D & $1622 \pm 117^{*}(\uparrow 135)$ & $549 \pm 24^{*}(\uparrow 33 \%)$ & $593 \pm 23^{*}(\uparrow 15 \%)$ \\
& Control & $14.48 \pm 3.44$ & $17.15 \pm 1.67$ & $28.64 \pm 2.31$ \\
GR & 2,4-D & $12.67 \pm 2.61$ & $16.88 \pm 1.45$ & $19.62 \pm 1.75^{*}(\downarrow 31 \%)$ \\
\hline
\end{tabular}

The parameters are expresed as in Table 7 . Each value is the mean \pm SEM. Values between brackets are $\%$ of increase $(\uparrow)$ or decrease $(\downarrow)$; ${ }^{*} \mathrm{p}<0.05, \mathrm{n}=6$ /group. $70 \mathrm{mg} 2,4-\mathrm{D} / \mathrm{kg} \mathrm{cw}$ of mother. Abbreviations as in the text.

Table 7. Oxidative parameters in ovary.

On analyzing the 2,4-D toxic effects on the ovary, Pochettino et al. (2010) found an increase in lipid peroxide (LPO) evidenced by augmented levels of malondialdehyde (MDA) and decrease antioxidant enzyme activity. These effects differed with age, while an increase in SeGPx activity was exceptionally observed at all ages (Table 7). These effects could reflect the natural diversity of rat ovarian cell types at different ages. Another explanation would be the well-known, protecting effect of estrogens against apoptosis and oxidative stress in a variety of tissues and cells (Spyridopoulos et al., 1997; Tomkinson et al., 1997; Garcia-Segura et al., 1998; Pelzer et al., 2000). Estrogens increase all ovarian weight, follicular growth, and the mitotic index of granulose cells, and also control granulosa cell apoptosis (Richards, et al., 1980; Bendell \& Dorrington, 1991) and have exerted varied antioxidant effects (Chatterjee \& Chatterjee 2009). Further studies are needed to analyze the time-course of the effects observed.

\subsection{Breast}

Pocchetino et al. (2010) observed that 2,4-D increased MDA levels at all ages (Table 8). It is known that MDA reflects the extent of oxidant status and is considered a good marker of oxidative stress (Wen et al., 2006). Both, singlet oxygen and hydroyl radicals have a high potential to initiate free-radical chain reactions in lipid peroxidation (Celik \& Tuluce, 2007). As the hydroyl radical level was unchanged in that study, 2,4-D could have stimulated LPO by increasing singlet oxygen levels. In addition, 2,4-D inhibited the activity of anti-oxidative enzymes such as CAT, Se-GPx, GR and GST (Table 9). 


\begin{tabular}{lcccc}
\hline & & PND 45 & PND 60 & PND 90 \\
\hline Hydroxyl & Control & $2.61 \pm 0.11$ & $3.04 \pm 0.11$ & $4.31 \pm 0.45$ \\
radical & 2,4-D & $2.65 \pm 0.44$ & $3.49 \pm 0.52$ & $4.49 \pm 0.11$ \\
Carbonyl & Control & $19.25 \pm 0.82$ & $28.57 \pm 3.86$ & $59.38 \pm 10.69$ \\
groups & 2,4-D & $21.34 \pm 5.47$ & $23.31 \pm 5.49$ & $57.37 \pm 14.89$ \\
Total & Control & $942 \pm 5$ & $1072 \pm 77$ & $3551 \pm 757$ \\
Thiols & 2,4-D & $951 \pm 25$ & $667 \pm 46^{*}(\downarrow 62 \%)$ & $1560 \pm 226^{*}(\downarrow 56 \%)$ \\
& Control & $52.62 \pm 1.57$ & $71.07 \pm 4.68$ & $158.41 \pm 2.59$ \\
MDA & 2,4-D & $70.65 \pm 7.48^{*}(\uparrow 34 \%)$ & $139.2 \pm 17.94^{*}(\uparrow 96 \%)$ & $217.8 \pm 18.95^{*}(\uparrow 37 \%)$ \\
& Control & $17.18 \pm 0.59$ & $19.41 \pm 1.51$ & $72.81 \pm 7.41$ \\
GST & 2,4-D & $10.41 \pm 1.91^{*}(\downarrow 40 \%)$ & $13.54 \pm 0.92^{*}(\downarrow 30 \%)$ & $32.35 \pm 5.98^{*}(\downarrow 55 \%)$ \\
& Control & $59.38 \pm 3.03$ & $137.62 \pm 10.73$ & $358.21 \pm 36.31$ \\
CAT & 2,4-D & $62.55 \pm 1.57$ & $81.27 \pm 2.55^{*}(\downarrow 41 \%)$ & $122.11 \pm 17.42^{*}(\downarrow 66 \%)$ \\
& Control & $538 \pm 44$ & $1430 \pm 31$ & $5596 \pm 1015$ \\
Se-GPx & 2,4-D & $198 \pm 19^{*}(\downarrow 63 \%)$ & $695 \pm 15^{*}(\downarrow 51 \%)$ & $2257 \pm 474^{*}(\downarrow 60 \%)$ \\
& Control & $15.94 \pm 0.91$ & $90.75 \pm 5.51$ & $228.81 \pm 14.31$ \\
GR & 2,4-D & $7.39 \pm 1.54^{*}(\downarrow 53.6 \%)$ & $60.02 \pm 9.05^{*}(\downarrow 34 \%)$ & $76.02 \pm 10.95^{*}(\downarrow 67 \%)$ \\
\hline
\end{tabular}

The parameters are expresed as in Table 7. Each value is the mean \pm SEM. Values between brackets are $\%$ of increase $(\uparrow)$ or decrease $(\downarrow)$; ${ }^{*} \mathrm{p}<0.05, \mathrm{n}=6$ / group. $70 \mathrm{mg} 2,4$-D/kg cw of mother. Abbreviations as in the text.

Table 8. Oxidative parameters in breast

Therefore, the decreased activity of anti-oxidative enzymes may decrease the protection against oxidants (Amstad et al., 1991).

In that regard, Dimitrova et al. (1994) suggested that the superoxide radicals, either by themselves or after transformation to $\mathrm{H}_{2} \mathrm{O}_{2}$, stimulate cysteine oxidation and inhibit the activity of the enzymes. Furthermore, Regoli \& Principato (1995) demonstrated that the flux of superoxide radicals inhibits CAT activity. Consequently, the decreased CAT activity might have reflected a flux of superoxide radicals promoted by 2,4-D. Moreover, GR also plays an important role in cellular antioxidant protection, catalyzing the reduction of glutathione disulfide (GSSG) to GSH (Kim et al., 2010).

Thus, the decrease in thiol groups could reflect GSH depletion in the breast. Therefore, 2,4-D produced oxidative imbalance, mainly during puberty and adulthood, probably because the gland is more sensitive to xenobiotics at these stages of development.

\section{In vitro studies}

It has been observed that 2.4-D concentrations of 1 to $2 \mathrm{mM}$ impaired neurite outgrowth, disrupted the cytoskeleton, and disorganized the Golgi apparatus in cultured cerebellar granule cells (CGC) (Rosso et al., 2000). Futhermore, Kaioumuva et al. (2001b) have demonstrated that the dimethylamonium salt of 2,4-D (DMA 2,4-D) at 0.1 to $5 \mathrm{mM}$ induces apoptosis in a dose- and time-dependent pattern in peripheral blood lymphocytes of healthy individuals and in Jurkat cells. Whereas, Tuschl \& Schwab (2003) showed that 4 to $16 \mathrm{mM}$ 2,4-D induces cytotoxic effects and apoptosis in HepG2 cells. 
In rat CGC, either 1 or $2 \mathrm{mM}$ 2,4-D induced similar increases of cellular death. The herbicide decreased significantly mean neuronal survival $(46.4 \%)$ after $48 \mathrm{~h}$, while no affect was observed after $24 \mathrm{~h}$ of treatment (Bongiovanni et al., 2007, 2011) (Fig. 2).

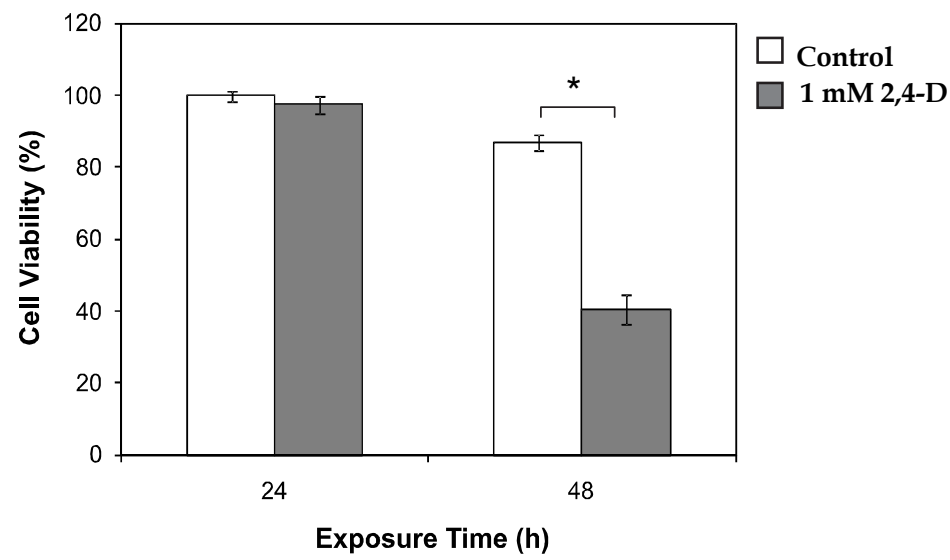

Fig. 2. Effect of 2,4-D on rat cerebellar granule cell viability. Cell cultures were incubated for 24 or $48 \mathrm{~h}$ in presence or ausence of $1 \mathrm{mM}$ 2,4-D. Values are means \pm SEM; * indicates $\mathrm{p}<0.001$ vs. control group; $\mathrm{n}=10$ /group.

Bongiovanni et al. $(2007,2010)$ studied oxidative stress as a possible mechanism of toxicity aiming to elucidate the mechanism of death induction by 2,4-D. Oxidative stress parameters were altered: ROS level and Se-GPx activity increased whereas CAT activity decreased at both treatment times ( 24 and $48 \mathrm{~h}$ ). GSH content was reduced only after $48 \mathrm{~h}$ of 2,4-D treatment. However, neither $\mathrm{Mn}-\mathrm{SOD}$ nor $\mathrm{Cu}, \mathrm{Zn}-\mathrm{SOD}$ activities nor reactive nitrogen species (RNS) levels were affected (Tables 9 \& 10). Interestingly, although the oxidative parameters evaluated were modified at the two time-limits studied, the cell viability only decreased at $48 \mathrm{~h}$ of treatment. This finding could be explained by a time dependency of this latter alteration.

\begin{tabular}{|c|c|c|c|c|}
\hline \multirow{2}{*}{ Parameters } & \multicolumn{2}{|c|}{$24 \mathrm{~h}$} & \multicolumn{2}{|c|}{$48 \mathrm{~h}$} \\
\hline & Control & $1 \mathrm{mM}$ 2,4-D & Control & $1 \mathrm{mM}$ 2,4-D \\
\hline ROS & $1.03 \pm 0.25$ & $\begin{array}{c}2.30 \pm 0,22^{*} \\
(\uparrow 123 \%)\end{array}$ & $2.28 \pm 0.35$ & $\begin{array}{c}4.13 \pm 0.32^{*} \\
(\uparrow 81 \%)\end{array}$ \\
\hline RNS & $7.45 \pm 1.13$ & $8.23 \pm 1.85$ & $4.82 \pm 0.27$ & $6.05 \pm 0.47$ \\
\hline GSH & $2.408 \pm 0.09$ & $2.225 \pm 0.09$ & $1.508 \pm 0.061$ & $\begin{array}{c}1.125 \pm 0.031^{*} \\
(\downarrow 25 \%)\end{array}$ \\
\hline
\end{tabular}

Parameters are expresed as micrograms per miligram of protein. Values between brackets are $\%$ of increase $(\uparrow)$ or decrease $(\downarrow)$; ${ }^{*} \mathrm{p}<0.001, \mathrm{n}=10$ /group. Abbreviations are indicated in the text.

Table 9. ROS, RNA and GSH levels (means \pm SEM) in rat cerebellar granule cell in culture for 24 or $48 \mathrm{~h}$ in presence or ausence of $1 \mathrm{mM}$ 2,4-D. 


\begin{tabular}{|c|c|c|c|c|}
\hline \multirow{2}{*}{ Enzimes } & \multicolumn{2}{|c|}{$24 \mathrm{~h}$} & \multicolumn{2}{|c|}{$48 \mathrm{~h}$} \\
\hline & Control & $1 \mathrm{mM}$ 2,4-D & Control & $1 \mathrm{mM}$ 2,4-D \\
\hline CAT & $30.97 \pm 1.26$ & $\begin{array}{c}15.80 \pm 1.23^{*} \\
(\downarrow 49 \%)\end{array}$ & $15.82 \pm 1.59$ & $\begin{array}{c}6.52 \pm 0.83^{*} \\
(\downarrow 59 \%)\end{array}$ \\
\hline$(\mathrm{Zn}, \mathrm{Cu}) \mathrm{SOD}$ & $10.43 \pm 1.23$ & $10.56 \pm 1.45$ & $8,49 \pm 1,20$ & $7.05 \pm 1.65$ \\
\hline (Mn) SOD & $4.45 \pm 0,88$ & $5.97 \pm 1.90$ & $2,86 \pm 1,90$ & $1.98 \pm 1.00$ \\
\hline Se-GPx & $9.71 \pm 1.20$ & $\begin{array}{c}39.75 \pm 2.90^{*} \\
(\uparrow 309 \%)\end{array}$ & $12.73 \pm 1.75$ & $\begin{array}{c}33.73 \pm 4.31^{*} \\
\quad(\uparrow 165 \%)\end{array}$ \\
\hline
\end{tabular}

Parameters are expresed as Units per miligram of protein. Values between brackets are \% of increase $(\uparrow)$ or decrease $(\downarrow)$; ${ }^{*} \mathrm{p}<0.001, \mathrm{n}=10$ /group. Abbreviations are indicated in the text.

Table 10. CAT, SODs and GPx activities (means \pm SEM) in rat cerebellar granule cells in culture for 24 or $48 \mathrm{~h}$ in presence or ausence of $1 \mathrm{mM} 2,4-\mathrm{D}$.

On using a PC-12 cell model, other authors have been previously shown that a depletion of mitochondrial and cytoplasmatic GSH results in increased ROS levels, disruption of the mitochondial transmembrane potential, rapid loss of mitochondial function, decrease in the ATP concentration, and eventually a higher cell death rate (Nieminen et al., 1995; Wüllner et al., 1999).

Therefore, the alteration in oxidative parameters suggest that the possible mechanisms of chlorophenoxy herbicide toxicity could involve dose-dependent cell membrane damage, uncoupling of oxidative phosphorylation, acetylcoenzyme disruption (Bradberry et al., 2000), and an indirect disruption of mitochondrial transmembrane potential which may lead to caspase inactivation (Kaioumova et al., 2001a). Mitochondrial structural modifications and increased permeability of the pores were also reported in association with a ROS increase (Belizário et al., 2007). In contrast, other studies suggest that 2,4-D cytotoxic effects are exerted by apoptosis induction via a direct effect on mitochondria (Tuschl \& Schwab, 2003).

In this regard, Bongiovanni et al. (2011), in agreement with De Moliner et al. (2002), demonstrated that 2,4-D induces apoptosis and necrosis in CGC. While De Moliner et al. (2002) showed that 2,4-D-induced apoptosis is associated with and increase in caspase-3 activity preceded by cytochrome-c release from mitochondria, the quantification of ultrastructural changes showed that $1 \mathrm{mM}$ 2,4-D stimulated neuronal death. As much as $49 \%$ of necrotic cells and $20 \%$ of apoptotic cells were observed, while only $31 \%$ of CGC presented normal growth with respect control group ( $p<0.001$; Fig. 3 compared with Fig. 4) (Bongiovanni et al., 2011). 

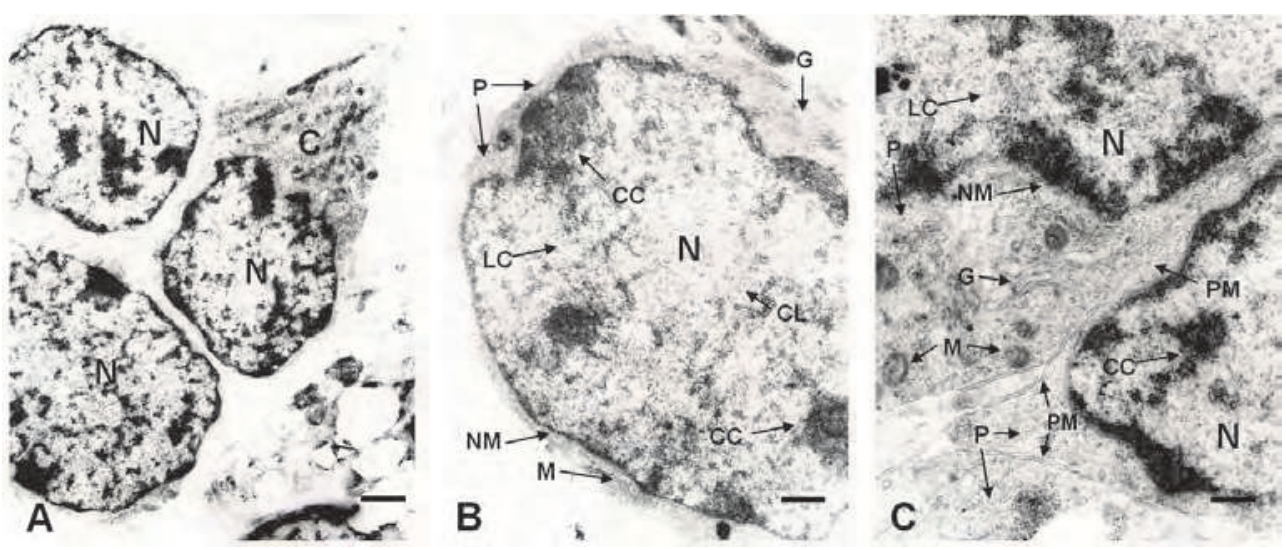

Fig. 3. Electron photomicrographies showing cerebellar granular neurons cultured in a control medium $(\mathrm{NaCl} 0.9 \%)$ for $48 \mathrm{~h}$. a-b. Cell morphology is preserved (nucleus with laxe chromatin, dense chromatin patch close to the nucleus envelope, scarce cytoplasm, and the presence of neurites). Bars correspond to $1 \mu \mathrm{m}$ in (a) and $160 \mathrm{~nm}$ in (b); c. Cells show preserved ultrastructural characteristics (Golgi apparatus, polyribosomes and mitochondrial characteristics of normal granular cerebellar cells). Bars correspond to $320 \mathrm{~nm}$ in (c). C cytoplasm, CC dense chromatin, G Golgi apparatus, LC laxe chromatin, M mitochondria, N nucleus, NM nuclear membrane, $\mathrm{P}$ polyribosome, PM plasmatic membrane.
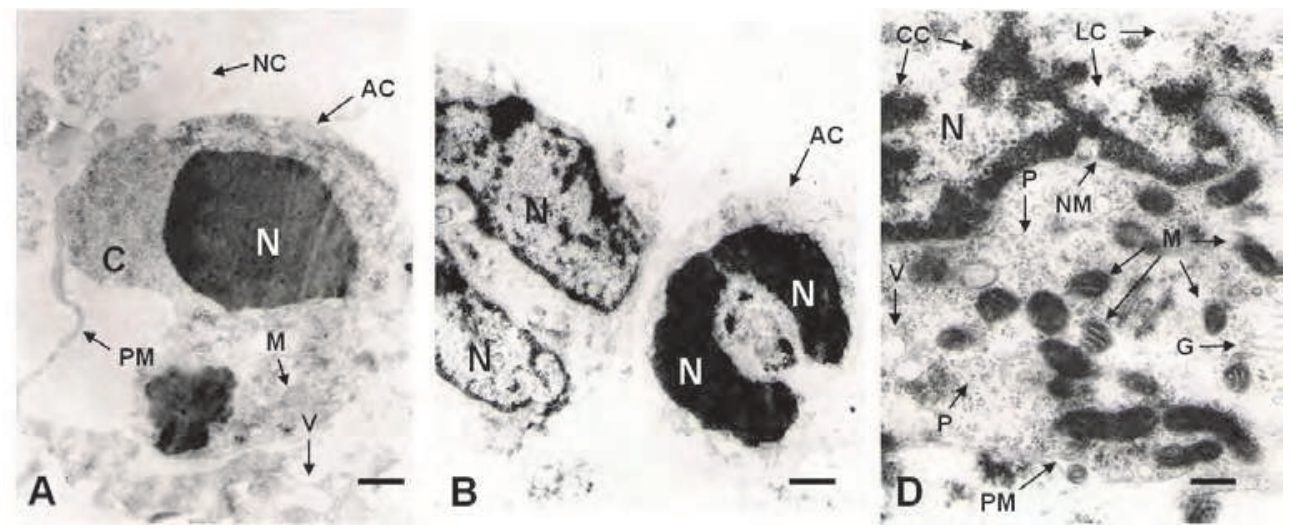

Fig. 4. Electron photomicrographies showing the ultrastructural cytoplasmatic characteristics of cerebellar granular cells after 2,4-D addition to the medium for $48 \mathrm{~h}$. a-b. An apoptotic cell (nuclear fragmentation and very dense chromatinic accumulus), a necrotic cell (cytoplasm very scarce, no nucleus), and cells with scarce cytoplasm and small nucleus are shown, allowing comparison with the control group (Cf Figs. 3a, b). Bars correspond to 1 $\mu \mathrm{m}$. c. A cell with cytoplasmatic protutions, vacuoles, disorganization of the cytoplasmatic reticulum, distended cisterns of the Golgi apparatus, and mitochondrial swelling. Bars correspond to $400 \mathrm{~nm}$. AC apoptotic cell, NC necrotic cell, V vacuole, and other abreviations in Fig. 3. 
In these studies, melatonin and amphetamine were used as phamacological tools aiming to improve the analysis of oxidative stress as a mechanism of toxicity, by assessing whether these compounds could be effective in preventing the toxic effect of 2,4-D in the redox balance of CGC in vitro (Bongiovanni et al., 2007, 2011).

A remarkable body of evidence indicates that melatonin exerts antioxidative protection in cell culture and in vivo systems (Pandi-Perumal et al., 2006). Regarding to 2,4-D toxicity, the oxidative stress induced by $1 \mathrm{mM} 2,4$-D was counteracted by the concomitant addition of 0.1 or $0.5 \mathrm{mM}$ melatonin in CGC cultures (Bongiovanni et al., 2007).

On the other hand, amphetamine has constistently been reported to accelerate the recovery of several functions in animals and humans with brain injury (Goldstein, 2000; Martinsson \& Eksborg, 2004). Amphetamine was also shown to stimulate both the dendritic growth in the ventral tegmental area (Mueller et al., 2006) and the neurotrophic and neuroplastic responses after brain damage (Moroz et al., 2004; Adkins \& Jones 2005). However, few data are available regarding any possible protective effect of amphetamine. In this regard, Bongiovanni et al., (2011) demonstrated that 1 or $10 \mu \mathrm{M}$ amphetamine reverted the 2,4-Dinduced apoptosis and oxidative stress in CGC. Nevertheless, amphetamine alone induced no significant changes with respect to the control culture. Noteworthy, at $1 \mu \mathrm{M}$ AMPH plus 2,4-D, 39\% of the cells were normal; $53 \%$ were necrotic, and $8 \%$ showed apoptosis. At $10 \mu \mathrm{M}$ AMPH plus 2,4-D, 57\% of the cells were normal, $43 \%$ were necrotic, and no apoptotic cells were observed by electron microscopy (Fig. 4 compared with Fig. 5).
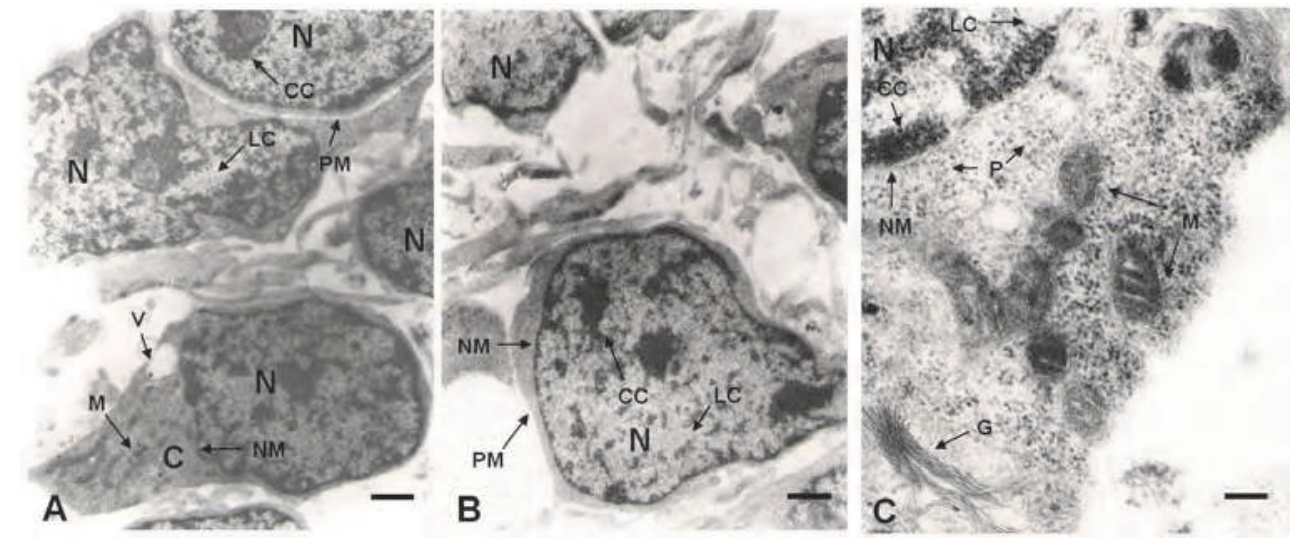

Fig.5. Electron photomicrographies showing the ultrastructural cytoplasmatic characteristics of cerebellar granular cells after 2,4-D and $10 \mu \mathrm{M}$ AMPH addition to the medium for $48 \mathrm{~h}$. ab. Cells present more conserved morphology (nucleus and cytoplasm) than those treated with 2,4-D alone (Cf Figs. 4a, b). Bars correspond to $1 \mu \mathrm{m}$. c. The cell shows mitochondria and Golgi cisterns more preserved than those of the cells treated with 2,4-D alone (Cf Fig. 4c). Bars correspond to $600 \mathrm{~nm}$. AC apoptotic cell, NC necrotic cell, V vacuole and other abreviations in Fig. 3.

The collected evidence would indicate a protective effect of melatonin and amphetamine against 2,4-D-induced cell death, possibly due to an inhibition of the oxidative mechanisms, as judged by the close relationship between ROS and apotosis induction (Carmody \& 
Cooter, 2001). While apoptosis and necrosis present some early features that may be common to both, mithocondrial disorders could be irreversibly compromised in necrotic, but not in apoptotic neurons (Nicotera \& Leist, 1997). This could explain why amphetamine decrease apoptosis but not necrosis in 2,4-D-treated cells.

In summary, 2,4-D would induce necrosis and apoptosis, the latter being possibly mediated by an oxidative imbalance.

\section{Concluding remarks}

A great body of evidence suggests that exposure to 2,4-D or to its ester or salt formulations is associated with a wide range of adverse effects in human and different animal species (Berkley \& Magee, 1963; Bortolozzi et al, 2001, 2003; Ferri et al., 2003, 2007; Konjuh et al., 2008; Stürtz et al., 2010).

Oxidative stress may affect the cells as a result of imbalance between the (physiological) production of potentially toxic ROS and some (physiological) scavenging activities (Park et al., 1999). Xenobiotics that interact with one or several complexes of the mitochondrial electron transport system, impairing the normal electron flow, may enhance ROS generation, leading to an imbalance between prooxidant species and cellular antioxidants (Jurado et al., 2011).

This review has analyzed the oxidative stress as a possible mechanism of toxicity by the herbicide 2,4-D. The collected evidence confirms that 2,4-D is an environmental pollutant that induces oxidative stress and could determine important deleterious changes in the development of the neural and reproductive systems in the studied models (Ferri et al., 2007; Bongiovanni et al., 2007, 2011; Pocchettino et al., 2010).

While the reported results showed that 2,4-D induces both necrosis and apoptosis, the evidence suggests that apoptosis would be mediated by or associated to an oxidative imbalance (Bongiovanni et al., 2011). Then, the oxidative stress would produce cytochromec release from mitochondria and a consequent activation of caspase- 3 in the affected cells (De Molliner et al., 2002). However, as mitochondria contribute to both apoptosis and necrosis, intracellular ATP and GSH could determine cell death by one or both of these mechanisms (Leist et al., 1997; Yutaka et al., 1997; Qian et al., 1999; Nieminen, 2003; Bongaerts, 2008). Therefore, the 2,4-D cytotoxic actions may involve some permissive effect on either necrosis or apoptosis induction.

Finally, the experimental evidence reported that 2.4-D can not only affect the nervous system or other hormone-sensitive organs, but also exert a very important, deleterious effect on embryonic and fetal development.

\section{Acknowledgment}

We thank Prof. Dr. Jose Luis Ferretti for his assistance in writing of the chapter.

\section{References}

Abdollahi, M., Ranjbar, A., Shadnia, S., Nikfar, S. \& Rezaie, A. (2004). Pesticides and oxidative stress: a review. Medical Science Monitor, Vol. 10, No. 6, (june 2004), pp.141-147, ISSN 1234-1010. 
Adkins, D.L. \& Jones, T.A. (2005). D-Amphetamine enhances skilled reaching after ischemic cortical lesions in rats. Neuroscience Letter, Vol. 380, No. 3, (June 2005), pp. 214218, ISSN 0304-3940.

Agarwal, A., Gupta, S. \& Sharma, R.K. (2005). Role of oxidative stress in female reproduction. Reproduction Biology and Endocrinology, Vol. 3, No. 28, (july 2005), pp , ISSN 1477-7827.

Agarwal, A., Gupta, S. \& Sikka, S. (2006). The role of free radicals and antioxidants in reproduction. Current Opinion in Obstetrics and Gynecology, Vol. 18, No. 3 (june 2006), pp. 325-332, ISSN 1040-872X.

Bagchi, M., Hassoun, E.A., Bagchi, D. \& Stohs, S.J. (1992). Endrin-induced increases in hepatic lipid peroxidation, membrane microviscosity, and DNA damage in rats. Archives of Environmental Contamination and Toxicology, Vol. 23, No. 1, (july 1992), pp. 1-5, ISSN 0090-4341.

Barnekow, D.E., Hamburg, A.W., Puvanesarajah, V. \& Guo, M. (2001). Metabolism of 2,4dichlorophenoxyacetic acid in laying hens and lactating goats. Journal of Agriculture and Food Chemistry, Vol. 49, No. 1, (January 2001), pp. 156-163, ISSN 0021-856.

Behrman, H. R., Kodaman, P. H., Preston, S. L. \& Gao, S. (2001). Oxidative stress and the ovary. Journal of Society for Gynecology and Investigation, Vol. 8, (1 Suppl Proceedings), (january 2001), pp. 40-42, ISSN 1071-5576.

Belizário, J.E., Alves, J., Occhiucci, J.M., Garay-Malpartida, M. \& Sesso, A. (2007). A mechanistic view of mitochondrial death decision pores. Brazilian Journal of Medical and Biological Research, Vol. 40, No. 8, (August 2007), pp. 1011-1024, ISSN 1678-451.

Bendell, J. J. \& Dorrington J. (1991). Estradiol-17 beta stimulates DNA synthesis in rat granulosa cells: action mediated by transforming growth factor-beta. Endocrinology, Vol. 128, No. 5, (may 1991), pp. 2663-2665, ISSN 0013-7227.

Blerkley M.C. \& Magee, K.R. (1963). Neuropathy following exposure to a dimethylamine salt of 2,4-D. Archives of Internal Medicine, Vol. 111, (March 1963), pp. 351-352, ISSN 0003-9926.

Bongaerts, P.A. (2008).What of apoptosis is important: the decay process or the causative origin? Medical Hypotheses, Vol. 70, No. 3, (February 2008), pp. 482-487, ISSN 03069877.

Bongiovanni, B., De Lorenzi, P., Ferri, A., Konjuh, C., Rassetto, M., Evangelista de Duffard, A.M., Cardinali, D.P. \& Duffard, R. (2007). Melatonin decreases the oxidative stress produced by 2,4-dichlorophenoxyacetic acid in rat cerebellar granule cells. Neurotoxicity Research, Vol. 11, No. 2, (February 2007), pp. 93-99, ISSN 1029-8428.

Bongiovanni, B., Ferri, A., Brusco, A., Rassetto, M., Lopez, L.M., Evangelista de Duffard, A.M. \& Duffard, R. (2011) Adverse effects of 2,4-dichlorophenoxyacetic acid on rat cerebellar granule cell cultures were attenuated by amphetamine. Neurotoxicity Research. 2011, Vol. 19, No. 4 (May 2011), pp. 544-555, ISSN 1029-8428.

Bortolozzi, A.; Duffard, R. \& Evangelista de Duffard, A. (1999). Behavioral alterations induced in rats by a pre- and postnatal exposure to 2,4-dichlorophenoxyacetic acid. Neurotoxicolology and Teratology, 21(4), (Jul-August 1999), pp. 4514-65, ISSN: 08920362.

Bortolozzi, A., Evangelista de Duffard, A.M., Dajas, F., Duffard, R., Silveira, R. (2001). Intracerebral administration of 2,4-diclorophenoxyacetic acid induces behavioral and neurochemical alterations in the rat brain. Neurotoxicology, Vol. 22, No. 2, (April 2001), pp. 221-232, ISSN 0161-813X. 
Bortolozzi, A.; Duffard, R. \& Evangelista de Duffard, A. (2003). Asymmetrical development of the monoamine systems in 2,4-dichlorophenoxyacetic acid treated rats. Neurotoxicology,24(1), (Jan 2003), pp. 149-157, ISSN: 0161-813X.

Bradberry, S.M., Watt, B.E., Proudfoot, A.T. \& Vale, J.A. (2000). Mechanisms of toxicity, clinical features, and management of acute chlorophenoxy herbicide poisoning: a review. Journal of Clinical Toxicology, Vol. 38, No. 2, () pp. 111-122, ISSN 0731-3810.

Brusco,A., Pecci Saavedra, J., Garcia, G., Tagliaferro, P., Evangelista de Duffard, A.M. \& Duffard, R. (1997). 2,4-Dichlorophenoxyactic acid through lactation induces astrogliosis in rat brain. Molecular and Chemical Neuropatology, Vol. 30, No. 3, (April 1997), pp. 175-185, ISSN 1044-7393.

Bukowska, B. (2003). Effects of 2,4-D and its metabolite 2,4-dichlorophenol on antioxidant enzymes and level ofglutathione in human erythrocytes. Comparative Biochemistry and Physiology (Part C), Vol.135, No. 4, (August 2003), pp.435-441, ISSN 1532-0456-

Carmody, R.J. \& Cotter, T.G. (2001). Signalling apoptosis: a radical approach. Redox Report, Vol. 6, No. 2, (April 2001), pp. 77-90, ISSN 1351-0002.

Casey, P.H. \& Collie, W.R. (1984). Severe mental retardation and multiple cogenital anomalies of uncertain cause after extreme parental exposure to 2,4-D, Journal of Pediatrics, Vol. 104, No. 2, (February 1984), pp. 313-315, ISSN 0022-3476.

Cazenave, J., Bistoni Mde, L. Pesce, S.F. \& Wunderlin, D.A. (2006). Differential detoxification and antioxidant response in diverse organs of Corydoras paleatus experimentally exposed to microcystin-RR. Aquatic Toxicology, Vol. 76, No. 1, (january 2006), pp.1-12, ISSN 0166-445X.

Celik, I. \& Tuluce Y. (2007). Determination of toxicity of subacute treatment of some plant growth regulators on rats. Environmental Toxicology, Vol. 22, No. 6, (december 2007), pp. 613-619, ISSN 1520-408.

Chatterjee, A. \& Chatterjee, R. (2009). How stress affects female reproduction: and overview. Biomedical Research, Vol. 20, No. 2, (august 2009), pp.79-83, ISSN 0970938X.

Crews, D., Willingham, E., \& Skiper, JK. (2000). Endocrine disruptors: present issues, future directions. The Quarterly Review of Biology, Vol. 75, No. 3, (september 2000), pp. 243260, ISSN 0033-5770.

De Moliner, K.L., Evangelista de Duffard, A.M., Soto, E., Duffard, R. \& Adamo, A.M. (2002). Induction of apoptosis in cerebellar granule cells by 2,4-dichlorophenoxyacetic acid. Neurochemical Research, Vol. 27, No. 11, (November 2002), pp. 1439-1446, ISSN 0364-3190.

Diaz, J. \& Samson, H. (1980). Impaired brain growth in neonatal rats exposed to ethanol. Science, Vol. 208, No. 4445, (May 1980), pp. 751-753, ISSN 0036-8075.

Dringen, R. (2000). Metabolism and funcions of glutathione in brain. Progress in Neurobiology, 62(6), (December 2000), pp. 649-671, ISSN: 0301-0082.

Duchnowicz, P., Koter, M. \& Duda, W. (2002). Damage of erythrocyte by phenoxyacetic herbicides and their metabolites. Pesticide Biochemistry and Physiology, Vol. 74, No.1, (September 2002), pp.1-7, ISSN 0048-3575.

Emerit, J., Edeas, M.\& Bricaire, F. (2004). Neurodegenerative diseases and oxidative stress. Biomedicine and Pharmacotherapy, Vol. 58, No. 1, (January 2004), pp. 39-46, ISSN 0753-3322.

Ferri, A., Bortolozzi, A., Duffard, R. \& Evangelista de Duffard, AM. (2000). Monoamine levels in neonate rats lactationally exposed to 2,4-dichlorophenoxyacetic acid. Biogenic Amines, Vol. 16, No. 1, (January 2000), pp. 73-100, ISSN 0168-8561.

Ferri, A., Duffard, R., Stürtz, N. \& Evangelista de Duffard, A.M. (2003) Iron, zinc and copper levels in brain, serum and liver of neonates exponed to 2,4-dichlorophenoxyacetic 
acid. Neurotoxicology and Teratology, Vol. 25, No. 5 ,(September - October 2003), pp. 607-613, ISSN0892-0362.

Ferri, A., Duffard, R. \& Evangelista de Duffard, A.M. (2007) Selective oxidative stress in brain areas of neonate rats exposed to 2,4-dichlorophenoxyacetic acid through mother's milk. Drug and Chemical Toxicology, Vol. 30, No. 1, (January 2007), pp.17-30, ISSN 0148-0545.

Garcia-Segura, L. M., Cardona-Gomez, P. , Naftolin, F. \& Chowen, J.A. (1998). Estradiol upregulates Bcl-2 expression in adult brain neurons. Neuroreport, Vol. 9, No. 4, (march 1998) pp. 593-597, ISSN 0959-4965.

Goldstein , L.B. (2000). Effects of amphetamines and small related molecules on recovery after stroke in animals and man. Neuropharmacology, Vol. 39, No. 5, (April 2000), pp. 852-859, ISSN 0028-3908.

Gonzalez, M., Soloneski, S., Reigosa, M.A. \& Larramendy, M.L. (2005). Genotoxicity of the herbicide 2,4-dichlorophenoxyacetic and a commercial formulation, 2,4Dichlorophenoxyacetic acid dimethylamine salt. I. Evaluation of DNA damage and cytogenetic endpoints in Chinese Hamster ovary $(\mathrm{CHO})$ cells. Toxicology In Vitro, Vol. 19, No. 2, (march 2005), pp. 289-297, ISSN 0887-2333.

Gupta, A., Agarwal, R. \& Shukla, G.S. (1999). Functional impairment of blood-brain barrier following pesticide exposure during early development in rats. Human Experimental Toxicology, Vol. 18, No. 3, (March 1999), pp. 174-179, ISSN 0960-3271.

Gupta, R. K., Schuh, R. A., Fiskum, G. \& Flaws, J.A. (2006). Methoxychlor causes mitochondrial dysfunction and oxidative damage in the mouse ovary. Toxicology and Applied Pharmacology, Vol. 216, No. 3, (november 2006) pp. 436-445, ISSN 0041-008X.

Halliwell, B. \& Gutteridge, J.M.C. (1998). Free Radicals in Biology and Medicine. (3rd Edition), Oxford University Press, ISBN 9780198500445, Oxford.

Huang, X., Atwoog, C.S., Hartshorn, M.A., Multhaup, G., Goldstein, L.E., Scarpa, R.C., Cuajungco, M.P., Lim, D.N., Moir, R.D., Tanzi, R.E. \& Bush, A.I. (1999). The A $\beta$ peptide of Alzheimer's disease directly produces hydrogen peroxide through metal ion reduction. Biochemistry, Vol. 38, No. 24, (May 1999), pp. 7609-7616, ISSN 00062960.

IARC. (1986). IARC Monographs on the Evaluation of the Carcinogenic Risk of Chemicals to Humans; Occupational Exposures to Chlorophenoxy Herbicides. In IARC Monographs on the Evaluation of Carcinogenic Risks to Humans (Lyon, France: IARC, World Health Organization), pp. 357-407.

Ishige, K., Chen, Q., Sagara, Y. \& Schubert, D. (2001).The Activation of Dopamine D4 Receptors Inhibits Oxidative Stress-Induced Nerve Cell Death. The Journal of Neuroscience, Vol. 21, No. 16, (August 2001), pp. 6069-6076, ISSN 0270-6474.

Jurado, A., Fernandes, M.A., Videira, R., Peixoto, F. \& Vicente J. (2011) Herbicides: The Face and the Reverse of the Coin. An in vitro Approach to the Toxicity of Herbicides in NonTarget Organisms. In: Herbicides and Environment, Andreas Kortekamp, pp. 1-44, InTech, ISBN 978-953-307-476-4,

Kaioumova, D., Kaioumov, F., Opelz, G. \& Süsa,l C. (2001a) Toxic effects of the herbicide 2,4-dichlorophenoxyacetic acid on lymphoid organs of the rat. Chemosphere, Vol. 43, No. 4-7, (May- June 2001), pp. 801-805, ISSN 0045-6535.

Kaioumova, D., Süsal, C. \& Opelz, G. (2001b) Induction of apoptosis in human lymphocytes by the herbicide 2,4-dichlorophenoxyacetic acid. Human Immunology, Vol. 62, No. 1, (January 2000), pp. 64-74, ISSN 0198-8859. 
Kaur, P., Kaur, G. \& Bansal, M.P. (2006). Tertiary-butyl hydroperoxide induced oxidative stress and male reproductive activity in mice: role of transcription factor NFkappaB and testicular antioxidant enzymes. Reproductive Toxicology, Vol. 22, No. 3 (october 2006) pp. 479-484, ISSN 0890-6238.

Kim, H.J., Park, Y.I. \& Dong, M.S. (2005). Effects of 2,4-D and DCP on the DHT-induced androgenic action in human prostate cancer cells. Toxicological Science, Vol. 88, No. 1, (August 2005), pp. 52-59, ISSN 1096-6080.

Kolb, B. \& Wishaw, Y.K. (1989). Plasticity in the neocortex mechanisms underlying recovery from early brain damage. Progress in Neurobiology, Vol. 32, No. 4, (September 1989), pp. 235-276, ISSN 0301-0082.

Konjuh, C., García, G., López, L., de Duffard, AM, Brusco, A \& Duffard, R.(2008). Neonatal hypomyelination by the herbicide 2,4-dichlorophenoxyacetic acid. Chemical and ultrastructural studies in rats. Toxicological Science, Vol. 104, No. 2, (August 2008), pp.332-340, ISSN 1096-6080.

Lee, J.Y., Baw, C.K., Gupta, S., Aziz, N. \& Agarwal, A. (2010). Role of Oxidative Stress in Polycystic Ovary Syndrome. Current Women's Health Reviews, Vol. 6, No. 2, (april 2010), pp.96-107, ISSN 1573-404.

Leist, M., Single, B., Castoldi, A.F., Kuhnle, S. \& Nicotera, P.(1997). Intracellular adenosine triphosphate (ATP) concentration: a switch in the decision between apoptosis and necrosis. The Journal of Experimental Medicine, Vol. 185, No. 8, (April 1997), pp.14811486, ISSN 0022-1007.

Martinsson, L. Eksborg, S. (2004). Drugs for stroke recovery: the example of amphetamines. Drugs Aging, Vol. 21, No. 2, (January 2004), pp. 67-79, ISSN 1170-229X.

Milton, N.G. (2004). Role of hydrogen peroxide in the aetiology of Alzheimer's disease: implications for treatment. Drugs Aging, Vol. 21, No. 2, (January 2004), pp. 81-100, ISSN 1170-229X.

Moroz, I.A., Peciña, S., Schallert, T. \& Stewart, J. (2004). Sparing of behavior and basal extracellular dopamine after 6-hydroxydopamine lesions of the nigrostriatal pathway in rats exposed to a prelesion sensitizing regime of amphetamine. Experimental Neurology, Vol. 189, No. 1, (September 2004), pp. 78-93, ISSN 00144886.

Mueller, D., Chapman, C.A. \& Stewart, J. (2006). Amphetamine induces dendritic growth in Ventral Tegmental area dopaminergic neurons in vivo via basic fibroblast growth factor. Neuroscience, Vol. 137, No. 3, (February 2006), pp. 727-735, ISSN 03064522.

Mukherjee, S., Koner, B. C., Ray, S. \& Ray, A. (2006). Environmental contaminants in pathogenesis of breast cancer. Indian Journal of Exprimental Biology, Vol. 44, No. 8, (august 2006), pp. 597-617, ISSN 0019-5189.

Munro, I.C., Carlo, G.L., Orr, J.C., Sund, K.G., \& Wilson, R.M. (1992). A comprehensive integrated review and evaluation of the scientific evidence relating to the safety of the herbicide 2,4-D. International Journal of Toxicology, Vol. 11, No. 5, (October 1992), pp. 559-664, ISSN 1091-5818.

Nicotera, P. \& Leist, M. (1997). Mitochondrial signals and energy requirement in cell death. Cell Death and Differentiation, Vol. 4, No. 6, (August 1997), 516-516, ISSN 1350-9047.

Nieminen, A.L., Saylor, A.K., Tesfal, S.A., Herman, B. E Lemasters, J.J. (1995). Contribution of mitochondrial permeability transition to lethal injury after exposure of hepatocyte to tbutylhydroperoxide. Biochemical Journal , Vol. 307, No. 1, (April 1995), pp. 99-106, ISSN 0264-6021.

Nieminen, A.L. (2003) Apoptosis and necrosis in health and disease: role of mitochondria. International Review of Cytology, Vol. 224, pp. 29-55, ISSN 0074-7696. 
Padros, J., Chun, D., Chen, L., Rigolli, P., Flarakos, T. \& Jurima-Romer, M. (2003). A cellbased assay for screening the uridine $5(')$-diphosphate-glucuronosyltransferase 1A inhibitory potential of new chemical entities. Analitical Biochemistry, Vol. 320, No. 2, (september 2003), pp. 310-312, ISSN 0003-2697.

Pandi-Perumal, S.R., Srinivasan, V., Maestroni, G.J.M., Cardinali, D.P., Poeggeler, B. and Hardeland, R. (2006). Melatonin: nature's most versatile biological signal?, Federation of European Biochemical Societies Journal, Vol. 273, No. 13, (July 2006), pp. 2813- 2838, ISSN 1742-4658.

Park, J.S., Wang, M., Park, S.J. \& Lee, S.H. (1999). Zinc finger of replication protein A, a nonDNA binding element, regulates its DNA binding activity through redox. Journal of Biological Chemistry, Vol. 274, No.41, (October 1999), 29075-29080, ISSN 0021-9258.

Pelzer, T., Schumann, M., Neumann, M., deJager, T., Stimpel, M., Serfling, E. \& Neyses, L. (2000). 17beta-estradiol prevents programmed cell death in cardiac myocytes. Biochemical and Biophysical Research Communications, Vol. 268, No. 1, (February 2000), pp. 192-200, ISSN 0006-291X.

Pietsch, C., Wiegand, C., Ame, M. Nicklisch, A., Wunderlin, D. \& Pflugmacher, S. (2001). The effects of a cyanobacterial crude extract on different aquatic organisms: evidence for cyanobacterial toxin modulating factors. Environmental Toxicology, Vol. 16, No. 6, (november 2001), pp. 535-542, ISSN 1520-4081.

Pochettino, A.A., Bongiovanni, B., Duffard, R.O. \& Evangelista de Duffard, A.M. (2011). Oxidative stress in ventral prostate, ovary, and breast by 2,4-dichlorophenoxyacetic acid in pre- and postnatal exposed rats. Environmental Toxicology, doi: 10.1002/tox.20690, ISSN 1522-7278.

Qian, T., Herman, B. \& Lemasters, J. (1999). The mitochondrial permeability transition mediates both necrotic and apoptotic death of hepatocytes exposed to Br-A23187. Toxicology and Applied Pharmacology, Vol.154, No. 2, (January 1999), pp.117-125, ISSN 0041-008X.

Richards, J. S., Jonassen, J. A. \& Kersey, K (1980). Evidence that changes in tonic luteinizing hormone secretion determine the growth of preovulatory follicles in the rat. Endocrinology, Vol. 107, No. 3, (September 1980), pp. 641-648, ISSN 0013-7227.

Rodier, P.M. (1995). Developing brain as a target of toxicity. Environmental Health Perspectives. Vol. 103, No. 6, (September 1995), pp. 73-76, ISSN 0091-6765.

Rosso, S.B., Garcia, G.B., Madariaga, M.J., Evangelista de Duffard, A.M. \& Duffard, R.O. (2000a). 2,4-Dichlorophenoxyacetic acid in developing rats alters behaviour, myelination and regions brain gangliosides pattern. Neurotoxicology, Vol. 21, No. 12, (February - April 2000), pp. 155-63, ISSN 0161-813X.

Rosso, S.B., Cáceres, A.O., Evangelista de Duffard, A.M., Duffard, R., Quiroga, S. (2000b). 2,4-Dichlorophenoxyacetic acid disrupts the cytoskeleton and disorganizes the Golgi apparatus of culture neurons. Toxicological Science, Vol. 56, No. 1, (July 2000), pp. 133-140, ISNN 1096-6080.

Sanders, C.A. \& Rogers, L.J. (1981). 2,4,5-Trichlorophenoxyacetic acid causes behavioral effects in chickens at environmentally relevant doses. Science, Vol. 211, No. 4482, (February 1981), pp. 593-595, ISSN 0036-8075.

Saradha, B., Vaithinathan, S. \& Mathur, P.P. (2008). Lindane alters the levels of HSP70 and clusterin in adult rat testis.Toxicology, Vol. 243, No.1-2, (january 2008), pp.116-123, ISSN 0300-483X.

Sjoden, P.O. \& Soderberg, U. (1972). Sex-dependent effects of prenatal 2,4,5 trichlorophenoxyacetic acid on rats open field behavior. Physiology and Behavior, Vol. 9, No. 3, (September 1972), pp. 357-360, ISSN 0031-9384. 
Spyridopoulos, I., A., Sullivan, B., Kearney, M. Isner, J.M. \& Losordo, D.W. (1997). Estrogen-receptor-mediated inhibition of human endothelial cell apoptosis. Estradiol as a survival factor. Circulation, Vol. 95, No. 6, (march 1997), pp. 15051514, ISSN 0009-7322.

Stürtz, N.; Evangelista de Duffard, A. \& Duffard, R. (2000). Detection of 2,4dichlorophenoxyacetic acid (2,4-D) residues in neonates breast-fed by 2,4-D exposed dams. Neurotoxicology, 21(1-2), (Feb-April 2000), pp. 147-154, ISSN: 0161-813X.

Stürtz, N., Bongiovanni, B., Rassetto, M., Ferri, A., Evangelista de Duffard, A.M. \& Duffard, R. (2006). Detection of 2,4-dichlorophenoxyacetic acid in rat milk of dams exposed during lactation and milk analysis of their major components. Food and Chemical Toxicology, Vol. 44, No. 1, (January 2006), pp. 8-16, ISSN 0278-6915.

Stürtz, N., Jahn, G.A., Deis, R.P., Rettori, V., Duffard, R.O. \& Evangelista de Duffard AM. (2010). Effect of 2,4-dichlorophenoxyacetic acid on milk transfer to the litter and prolactin release in lactating rats. Toxicology, Vol. 271, No.1-2, (April 2010), pp. 13-20, ISSN 0300-483X.

Sulik, M., Kisielewski, W., Szynaka, B., Kemona, A., Sulik, A., Sulkowska, M. \& Baltaziak, M. (1998). Morphological changes in mitochondria and lysosomes of hepatocytes in acute intoxication with 2,4-dichlorophenoxyacetic acid (2,4-D). Materia Medica Polona, Vol. 30, No. 1-2, (January-June 1998), pp.16-19, ISSN 0025-5246.

Symonds, D. A., Merchenthaler, I. \& Flaws, J. A. (2008). Methoxychlor and estradiol induce oxidative stress DNA damage in the mouse ovarian surface epithelium. Toxicological Science, Vol. 105, No. 1, (), pp.182-187, ISSN 1096-0929.

Tilson, H.A. (1998). Developmental neurotoxicology of endocrine disruptors and pesticides: identification of information gaps and research needs. Environmental Health Perspectives. Vol. 106, No. 3, (June 1998), pp. 807-811, ISSN 0091-6765.

Tomkinson, A., Reeve, J., Shaw, R.W. \& Noble, B.S. (1997). The death of osteocytes via apoptosis accompanies estrogen withdrawal in human bone. Journal of Clinical Endocrinology and Metabolism, Vol. 82, No. 9, (september 1997), pp. 3128-3135, ISSN 0021-972X.

Tuschl, H. \& Schwab, S. (2003) Cytotoxic effects of the herbicide 2,4-dichlorophenoxyacetic acid in HepG2 cells. Food and Chemical Toxicology, Vol. 41, No. 1, (March 2003), pp. 385-393, ISSN 0278-6915.

U.S.E.P.A. Edwards, D. (2006). Reregistration Eligibility Decision for 2,4-D. Prevention, Pesticides EPA 738-R-05-002. Environmental Protection and Toxic Substances (June 2005). Agency (7508C).

Wüllner, U., Seyfried, J., Groscurth, P., Beinroth, S., Winter, S., Gleichmann, M., Heneka, M., Löschmann, P., Schulz, J.B., Weller, M. \& Klockgether, T. (1999). Glutathione depletion and neuronal cell death: the role of reactive oxygen intermediates and mitochondrial function. Brain Research, Vol. 826, No. 1, (April 1999), pp-53-62, ISSN 00068993.

Yama, O. E., Duru F.I.O., Oremosu A.A. \& Noronha C.C. (2011). Testicular oxidative stress in Sprague-Dawley rats treated with bitter melon (Momordica charantia): the effect of antioxidant supplementation. Bangladesh Journal of Medical Science, Vol.10, No. 2, (april 2011), pp 104-111, ISSN 2223-4721.

Yutaka, E., Shigeomi, S. \& Yoshihide, T. (1997). Intracellular ATP levels determine cell death fate by apoptosis or necrosis. Cancer Research, Vol. 57 (10), (May 1997), pp. 18351840, ISSN 0008-5472. 


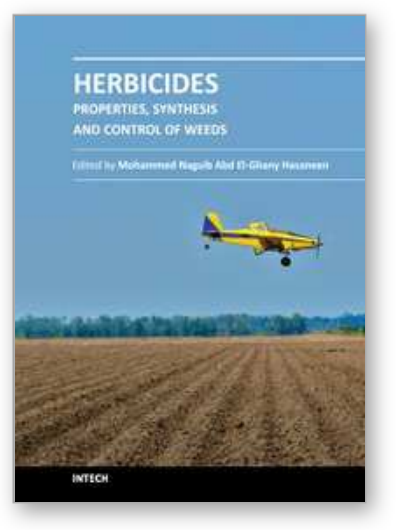

\author{
Herbicides - Properties, Synthesis and Control of Weeds \\ Edited by Dr. Mohammed Nagib Hasaneen
}

ISBN 978-953-307-803-8

Hard cover, 492 pages

Publisher InTech

Published online 13, January, 2012

Published in print edition January, 2012

This book is divided into two sections namely: synthesis and properties of herbicides and herbicidal control of weeds. Chapters 1 to 11 deal with the study of different synthetic pathways of certain herbicides and the physical and chemical properties of other synthesized herbicides. The other 14 chapters (12-25) discussed the different methods by which each herbicide controls specific weed population. The overall purpose of the book, is to show properties and characterization of herbicides, the physical and chemical properties of selected types of herbicides, and the influence of certain herbicides on soil physical and chemical properties on microflora. In addition, an evaluation of the degree of contamination of either soils and/or crops by herbicides is discussed alongside an investigation into the performance and photochemistry of herbicides and the fate of excess herbicides in soils and field crops.

\title{
How to reference
}

In order to correctly reference this scholarly work, feel free to copy and paste the following:

Bettina Bongiovanni, Cintia Konjuh, Arístides Pochettino and Alejandro Ferri (2012). Oxidative Stress as a Possible Mechanism of Toxicity of the Herbicide 2,4-Dichlorophenoxyacetic Acid (2,4-D), Herbicides Properties, Synthesis and Control of Weeds, Dr. Mohammed Nagib Hasaneen (Ed.), ISBN: 978-953-307-8038, InTech, Available from: http://www.intechopen.com/books/herbicides-properties-synthesis-and-control-ofweeds/oxidative-stress-as-a-possible-mechanism-of-toxicity-of-the-herbicide-2-4-dichlorophenoxyacetic-acid

\section{INTECH}

open science | open minds

\section{InTech Europe}

University Campus STeP Ri

Slavka Krautzeka 83/A

51000 Rijeka, Croatia

Phone: +385 (51) 770447

Fax: +385 (51) 686166

www.intechopen.com

\section{InTech China}

Unit 405, Office Block, Hotel Equatorial Shanghai

No.65, Yan An Road (West), Shanghai, 200040, China

中国上海市延安西路65号上海国际贵都大饭店办公楼 405 单元

Phone: +86-21-62489820

Fax: $+86-21-62489821$ 
(C) 2012 The Author(s). Licensee IntechOpen. This is an open access article distributed under the terms of the Creative Commons Attribution 3.0 License, which permits unrestricted use, distribution, and reproduction in any medium, provided the original work is properly cited. 